\title{
Causes of cost overruns on infrastructure projects in Saudi Arabia
}

\author{
Fahad S. Allahaim* \\ and Li Liu
}

Faculty of Engineering and IT, School of Civil Engineering,

The University of Sydney,

Building J05, NSW, 2006, Australia

Email: fall5762@uni.sydney.edu.au

Email: li.liu@sydney.edu.au

${ }^{*}$ Corresponding author

\begin{abstract}
This paper reports an up-to-date ranked list of causes of cost overrun in Saudi Arabia from a survey of 160 project managers of infrastructure projects. The top five causes were market conditions, design changes, the practice of assigning a contract to the lowest bidder, delays and design error. Assigning a contract to the lowest bidder is not ranked in the top five reasons in other countries. Other factors contributing to cost overrun of Saudi infrastructure projects include lack of contractor and consultant planning before the project, poor coordination with government agencies and parallel contracts, inconsistent management strategy, poor client staff communication and stakeholders' lack of participation during the conceptual phase. A cause unique to Saudi Arabia is due to the time it takes the Labour Ministry to issue labour visas to non-national workers.
\end{abstract}

Keywords: cost overrun; cost overrun causes; infrastructure projects; Saudi Arabia.

Reference to this paper should be made as follows: Allahaim, F.S. and Liu, L. (2015) 'Causes of cost overruns on infrastructure projects in Saudi Arabia', Int. J. Collaborative Enterprise, Vol. 5, Nos. 1/2, pp.32-57.

Biographical notes: Fahad S. Allahaim has a Bachelor of Architecture and Building Science, King Saud University, Saudi Arabia and a Master's degree with honours in Design Science, Building Services/Technology and Facility Management, University of Sydney, Australia. He is a Lecturer at the College of Architecture and Planning at King Saud University where he works in the Sustainable Infrastructure Planning System project. He is a $\mathrm{PhD}$ candidate at the School of Civil Engineering, University of Sydney. His PhD research focuses on understanding and classifying the causes of cost overrun on infrastructure projects and he has developed a risk-based cost contingency estimation model for infrastructure projects.

Li Liu, PhD, is a Senior Lecturer at the University of Sydney (USYD). He has a PhD from the Australian Graduate School of Management (AGSM), a M.Tax from USYD, an MBA and a BE. He has one decade of experience in systems engineering, project management and business research. 
He has served as reviewers for a number of journals and conferences and has served as a Senior Editor for Journal of Information Technology. His research focuses on the performance of infrastructure projects, organisational project management, organisational learning in project organisations, IT/IS project management, organisational control theory and project/program governance.

\section{Introduction}

A significant proportion of large infrastructure projects have experienced substantial cost overrun which has led to financial or fiscal distress to project stakeholders and resulted in the deferral or cancellation of other projects (Flyvbjerg, 2014). High profile examples include the Big Dig project in Boston (USA) which had a cost overrun of $220 \%$; the Wembley Stadium (UK) which experienced a 50\% cost overrun (Flyvbjerg, 2014); and the Parliament Building (Scotland) which was over three years late and experienced more than 900\% cost overrun (Love et al., 2012). According to Flyvbjerg et al. (2005) and Flyvbjerg (2009), the average cost overrun for large-scale infrastructure projects ranges from $20.4 \%$ to $44.7 \%$; and nine out of 10 projects have cost overruns worldwide.

In Saudi Arabia, a period of accelerated growth is expected. With SR2.358 trillion (US\$629 billion) to be invested in projects over five years to meet Saudi Arabia's growing infrastructure needs (Al-Arabia, 2012), Saudi infrastructure projects are not immune from cost overruns. Studies reported that $41 \%-50 \%$ of infrastructure projects in Saudi Arabia overrun its budget (Althunian, 2010; Alguwaihes, 2011) and the extent of cost overrun is substantial.

Despite the increase in investment in infrastructure projects and the reported cost overruns (Alguwaihes, 2011; Althaqafy, 2012), there is a noticeable lack of research on infrastructure project performance and risk factors for projects undertaken in Saudi Arabia (Mitra and Tan, 2012).

There is a need for up-to-date knowledge about causes of cost overrun, which is related to the geographical location, cultural practice, governance systems (Cantarelli et al., 2012) as well as project management practice. This research contributes to the understanding of the main causes of cost overruns in infrastructure projects in Saudi Arabia. The findings help Saudi project managers to identify key risk factors of cost overruns for their projects and so as to effectively plan for the mitigation of these risk.

Below, literature is reviewed and the research design outlined. In the analysis section, cost overrun causes are ranked using an importance index, followed by a comparison of the findings with other studies. Finally, conclusions are drawn and recommendations made.

\section{Literature review}

Identifying the causes of cost overrun of infrastructure projects is necessary to understand the causes and effectively manage the risks. This section reviews the literature on the 
performance of infrastructure projects conducted since 1988, in date order by location, and then reviews the causes of cost overruns.

The existing literature reports that cost overrun in large projects is a sizeable problem. Figure 1 summarises 19 studies conducted from 1990 to 2012 on cost overrun in transport projects around the world. It shows that, depending on the type of projects, the mean cost overrun ranges from $5 \%$ to $105 \%$ (Figure 1 ).

Figure 1 Summary of cost overruns for transport projects from various studies (1990-2012)

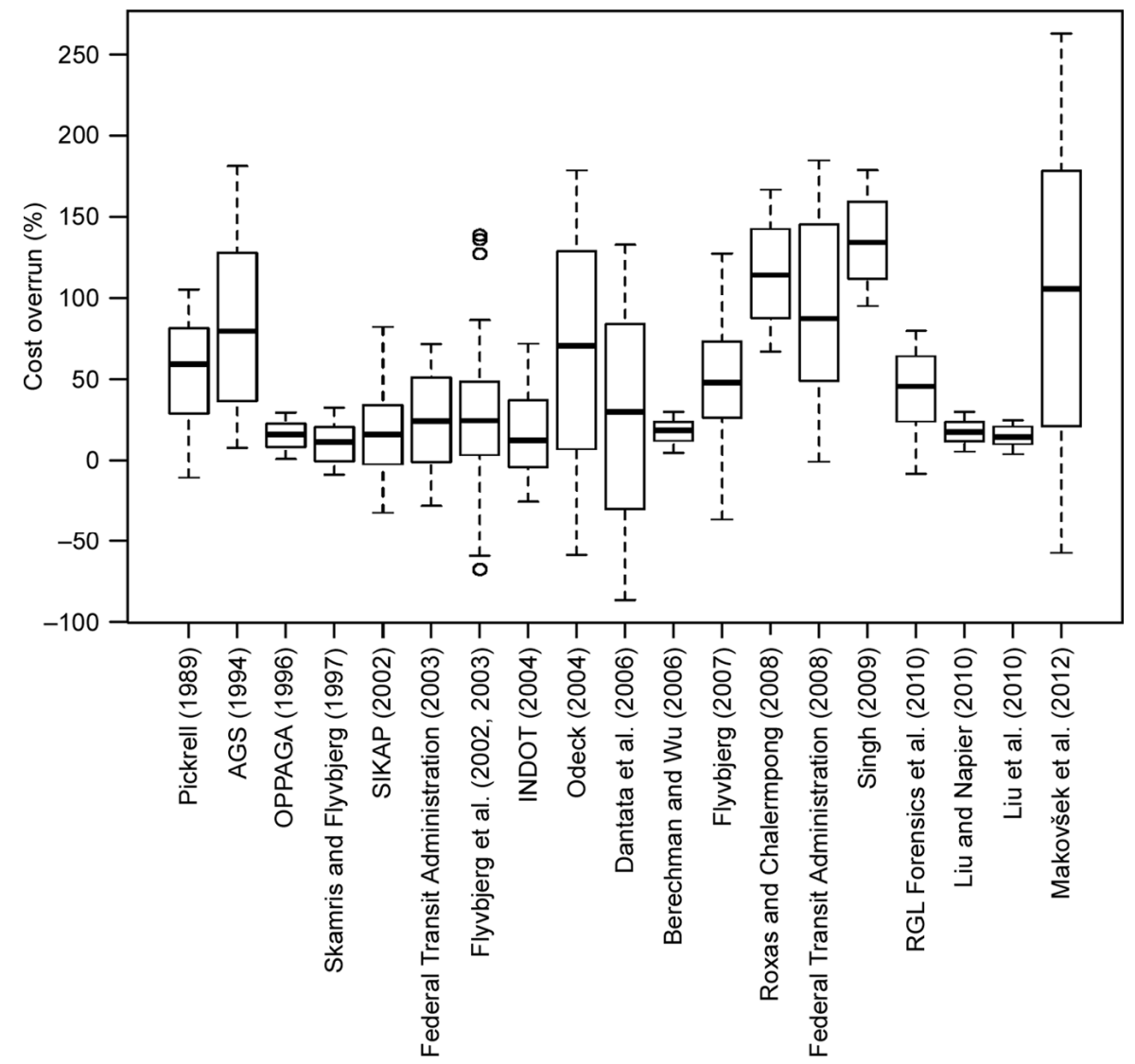

The median cost overrun percentage in each study is marked by the solid line in the 'box' and ranges from $5 \%$ to $105 \%$, while the box is derived from the lower and upper quartile values. The minimum and maximum cost overrun percentages in each study, which range from about $-80 \%$ to $260 \%$, are displayed with vertical lines ('whiskers') connecting the points to the centre box. The shape of the box in most studies is symmetric. The study by Flyvbjerg et al. $(2002,2003)$ has obvious outlier (dots) which range from $-60 \%$ to $150 \%$.

Infrastructure projects in each continent are different as culture and governance systems may vary across continents. The review of literature below on cost overrun causes is organised around the continents of Europe, USA, Australia, Middle East, Asia and Africa. 
Table 1 Summary of the literature on causes of cost overrun by decade and by continent

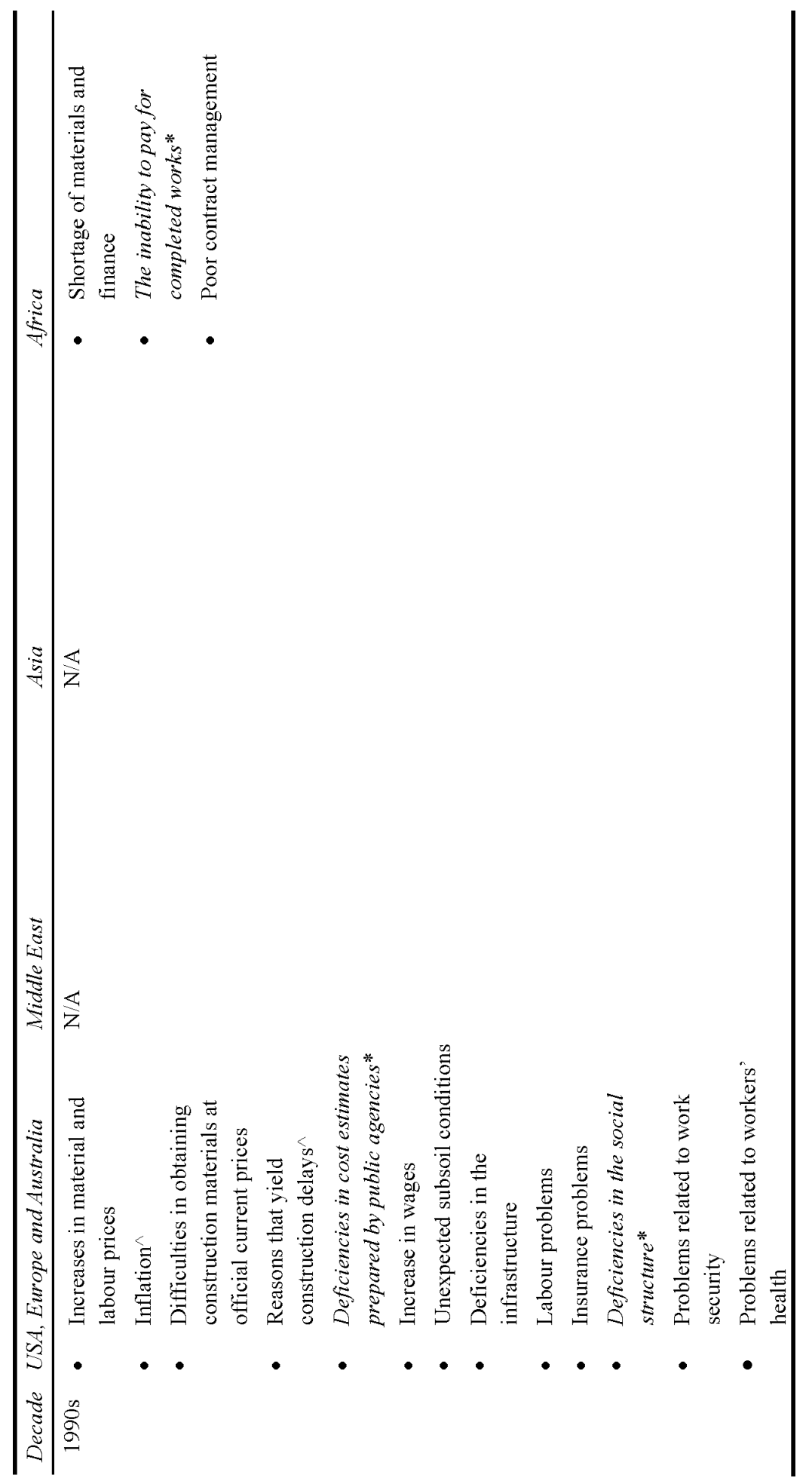


Table 1 Summary of the literature on causes of cost overrun by decade and by continent (continued)

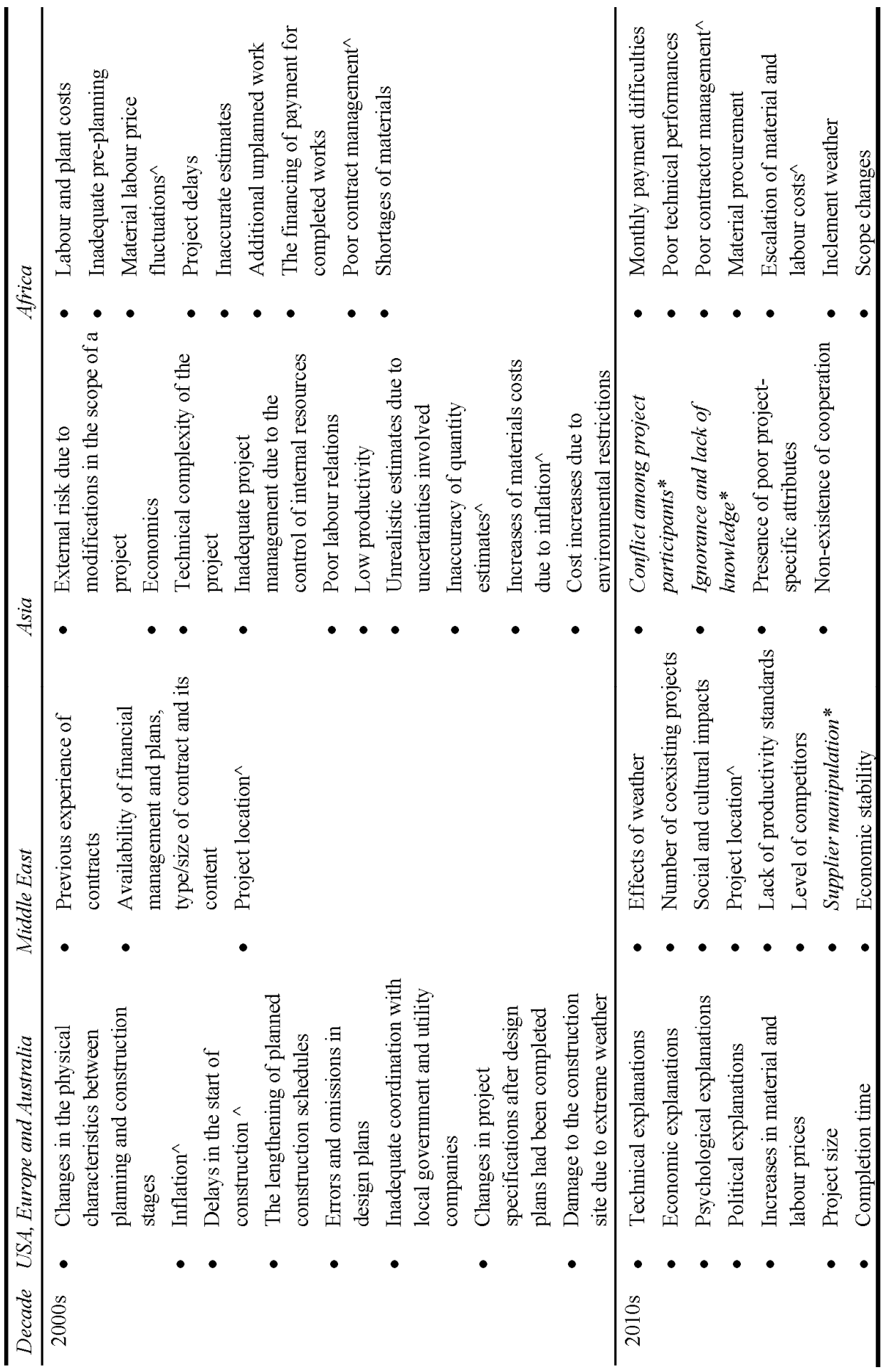


Table 1 Summary of the literature on causes of cost overrun by decade and by continent (continued)

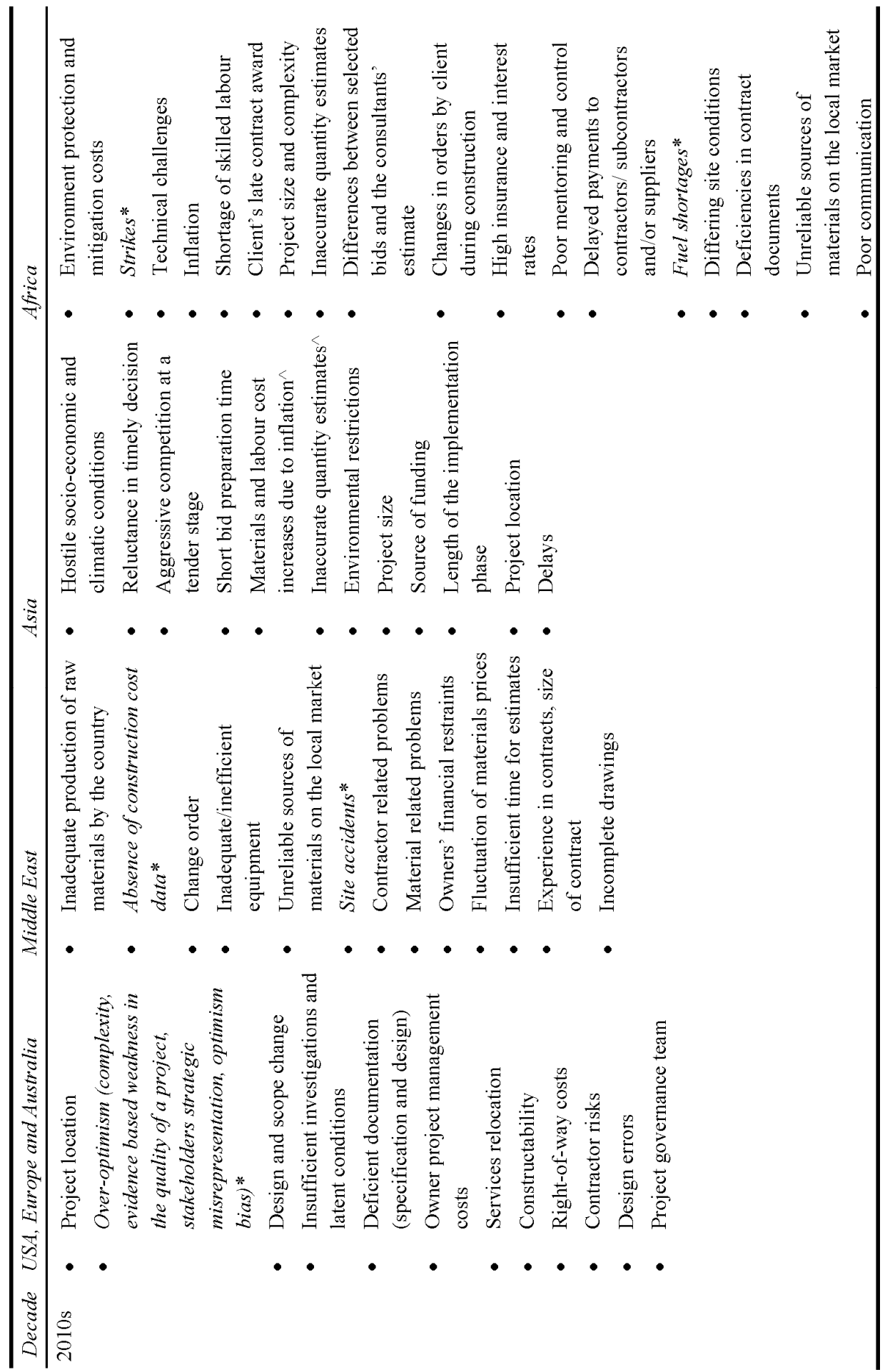


Table 1 Summary of the literature on causes of cost overrun by decade and by continent (continued)

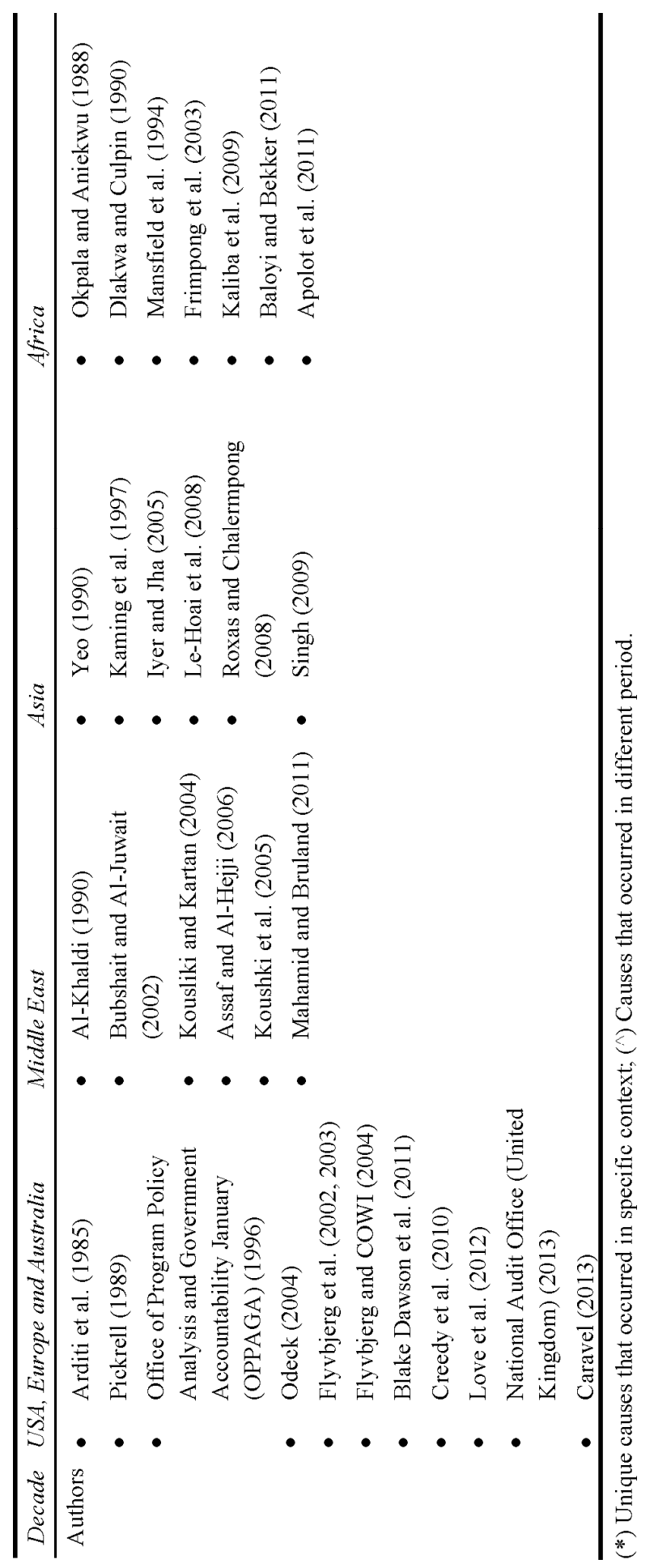


There are an enormous number of studies covering causes of cost overrun worldwide. Table 1 summarises the findings of selected previous studies on causes of cost overrun by decade and by continent. There are unique causes by continent. For instance, in USA, Europe and Australia, causes include deficiencies in cost estimates prepared by public agencies, deficiencies in the social structure, over-optimism and project governance team. In the Middle East, causes include supplier manipulation, absence of construction cost data, and site accidents. In Asia, causes include conflict among project participants and ignorance and lack of knowledge. Causes in Africa include the inability to pay for completed works, strikes and fuel shortages.

By infrastructure type, transport projects have had the most attention in all continents while education, health and water projects have received only limited attention. In most previous studies, technical factors such as project location, project size, scope change and fluctuations in the prices of materials and labour due to inflation have frequently been identified as major causes in most areas, especially in transport and water projects, while design error has been identified for education and health projects. However, some studies indicated that over-optimism is a major cause for infrastructure projects in general.

Project management practice changes over time project management knowledge improves and the greater social economic environment evolves. Every 2-5 years there are studies conducted on cost overrun causes (see Figure 1 and Table 1). These studies presented a variety of cost overrun causes that occurred in each decade from 1990 to 2013, which revealed that the top cost overrun causes change over time. As a result, there is a need for up-to-date knowledge about causes of cost overrun, which helps to understand the complexity of these causes and mitigate the risk. In Saudi Arabia, the central government has tried to improve the problem of project failure, especially in large-scale projects, by establishing authorities for mentoring projects under construction. Large-scale projects are prone to cost overrun. Between 1992 to 2009, 82\% of Saudi infrastructure projects failed to meet their baseline time, cost and quality objectives with an average cost overrun of 40\% (Althunian, 2010). According to Alguwaihes (2011), $25 \%$ of Saudi infrastructure projects were delivered at the estimated cost and time. However, $50 \%$ failed to meet the baseline time, cost and quality objectives and $25 \%$ failed to deliver (Althaqafy, 2012).

There appears to be a lack of research on infrastructure project performance in Saudi Arabia (Mitra and Tan, 2012). Prior to the construction boom in 2005, Al-Khaldi (1990) examined factors contributing to construction costs in water projects and Bubshait and Al-Juwait (2002) studied causes of cost overruns in buildings. Other studies include Zain Al-Abidien (1983), Al-Sultan (1987), Assaf et al. (1995), Al-Khalil and Al-Ghafly (1999), Assaf and Al-Hejji (2006), and Al-Kharashi and Skitmore (2009) on construction project delays in Saudi Arabia. More recently, Jomaah et al. (2014) identified, assessed and evaluated risks that affect construction projects for education in Saudi Arabia.

Global studies on the causes of cost overruns in infrastructure projects may provide assistance in identifying major causes in Saudi Arabia. However, due to differences in governance systems, geographical location or cultural practice, studies focusing on infrastructure projects in Saudi Arabia are needed to identify causes of overrun unique to the country's infrastructure projects. 


\section{Research design}

To examine the causes of cost overrun in Saudi Arabia, a survey of 160 infrastructure project managers in Saudi Arabia was conducted.

Based on the literature review of cost overrun causes, a questionnaire on the impacts of each of the causes was developed. Table 2 lists the 41 causes most frequently identified from 25 selected studies summarised in Table A1.

Table 2 Most frequent causes of cost overrun identified in the literature

\begin{tabular}{|c|c|c|}
\hline No. & Causes of cost overrun & $\begin{array}{c}\text { Frequency in } \\
25 \text { studies }\end{array}$ \\
\hline 1 & Market conditions (materials and labour) & 14 \\
\hline 2 & Inflation & 12 \\
\hline 3 & Site constraints & 12 \\
\hline 4 & Unrealistic contract duration and requirements imposed & 12 \\
\hline 5 & Delays (e.g., in decision making, in approval of drawings) & 12 \\
\hline 6 & Contractor's poor site management and supervision skills & 11 \\
\hline 7 & Design error & 9 \\
\hline 8 & Slow payment of completed works & 9 \\
\hline 9 & Practice of assigning contract to lowest bidder & 8 \\
\hline 10 & Cash flow during construction & 8 \\
\hline 11 & Project size & 8 \\
\hline 12 & Equipment availability and failure & 8 \\
\hline 13 & Poor financial control on site & 8 \\
\hline 14 & Laws and regulatory frameworks & 8 \\
\hline 15 & Weather conditions & 8 \\
\hline 16 & Monthly payment difficulties from agencies (e.g., contractor, owner) & 7 \\
\hline 17 & Labour, insurance, work security or workers' health problems & 7 \\
\hline 18 & Additional works and rework & 7 \\
\hline 19 & Lack of experience of project (e.g., location, type) & 7 \\
\hline 20 & Incorrect planning and scheduling by contractors & 7 \\
\hline 21 & Changes in material specifications and type & 7 \\
\hline 22 & Social and culture impact (e.g., problems with neighbours) & 7 \\
\hline 23 & Waste on site & 7 \\
\hline 24 & Fluctuation in money exchange rate & 6 \\
\hline 25 & Deficiencies in the infrastructure & 6 \\
\hline 26 & Inadequate modern equipment (technology) & 6 \\
\hline 27 & Failure to price in certain risks & 6 \\
\hline 28 & Lack of constructability & 6 \\
\hline
\end{tabular}


Table 2 Most frequent causes of cost overrun identified in the literature (continued)

\begin{tabular}{llc}
\hline No. & Causes of cost overrun & $\begin{array}{c}\text { Frequency in } \\
\text { 25 studies }\end{array}$ \\
\hline 29 & Change in the scope of the project & 6 \\
30 & Obstacles from government & 6 \\
31 & Political complexities & 6 \\
32 & Fraudulent practices & 6 \\
33 & High interest rates charged by bankers on loans & 5 \\
34 & Shortage of site workers & 5 \\
35 & Design changes & 5 \\
36 & Heritage material discovery & 5 \\
37 & Late delivery of materials and equipment & 4 \\
38 & Inadequate specifications & 4 \\
39 & Deficiencies in cost estimates prepared by public agencies & 4 \\
40 & Optimism bias* & 2 \\
41 & Strategic misrepresentation* & 2 \\
\hline
\end{tabular}

Causes are listed in order of frequency, based on Table A1.

(*) As Flyvbjerg published various papers on causes of cost overrun for infrastructure projects in which he discussed optimism bias and strategic misrepresentation - which were widely and frequently cited - these two causes are considered as frequent causes and listed in this study.

The questionnaire asked the respondents about their most recent completed infrastructure projects with contract value greater than 50 million Saudi Riyals (US\$15 million), excluding operational and maintenance costs. The questionnaire consists of three sections. The first section asks about the participants' backgrounds and their organisation, their work experience, academic qualifications, the number of projects in which they had been involved in the last 20 years, the location of these projects, the type of projects and their experience with cost overruns throughout the specified period. In the second section, the participants were asked to rate the frequency of occurrence of 41 causes of cost overrun using Likert-scale response anchors, where Never $(\mathrm{N})=1$, Occasionally $(\mathrm{OC})=2$, Sometimes $(\mathrm{S})=3$, Often $(\mathrm{O})=4$ and Always $(\mathrm{A})=5$. The last section of the questionnaire elicited general comments from the respondents. This section was designed to allow respondents to add any further causes in addition to the list of causes in the questionnaire based on their most recent involvement in a project regarding the major causes of cost overrun. The survey was designed in English and then translated into Arabic. The survey was distributed online through the SurveyMonkey website in two languages, English and Arabic.

A pilot study with 15 respondents was conducted to test and improve the face validity of the questions. The researcher presented the survey to respondents who were involved in infrastructure projects and had agreed to take part in the pilot study. The researcher and respondents met face-to-face to provide feedback on the clarity and appropriateness of the questions in addressing the aims of the research project. The pilot respondents also checked the accuracy of the translation of the questionnaire from English to Arabic. 
The revised questionnaire was tested further using an online survey with five respondents who were involved in infrastructure projects.

In Saudi Arabia, there are three main organisations that oversee engineers, contractors and consultants: the Saudi Council for Engineers (SCE), the Ministry of Municipal and Rural Affairs (MoMRA) and the Chamber of Commerce and Industry (CoCI). Their databases were used to distribute the questionnaire to their members and also to gather information and contact details about the participants. The sample selected from each of the three groups included owners representing the government agency (key decision makers) responsible for the projects, consultants working on infrastructure projects (project managers), and contractors involved in infrastructure projects (project managers).

Of the 400 targeted participants, 153 participants returned the questionnaire. After including the 15 face-to-face surveys conducted in the pilot study and removing the eight surveys with missing values, the total number of responses was 160 , a $40 \%$ response rate. Of those who completed the questionnaire, $23 \%$ were owners, $52 \%$ were contractors and $25 \%$ were consultants.

The average age of the respondents was 40 years old and over. Most of the respondents had either a bachelor or a postgraduate qualification. Most respondents had more than 10 years experience in infrastructure projects. The respondents represented all 13 regions in Saudi Arabia, with the majority of respondents coming from the main region of Riyadh (59\%), followed by the Eastern region (23\%), Makkah Al-Mukarramah region (19\%) and Al-Madinah Al-Munawarah region (13\%).

Data collection was based on the self-report method and that may be threatened by common method bias, which is a possible problem in behavioural research (Podsakoff et al., 2003). The results of the Harman single-factor test recommended by Podsakoff et al. (2003) showed that no one general factor accounts for the majority of variance in the measurement items as the ratio of explained variance was $24.67 \%$, which is below $50 \%$ (Cheng et al., 2011) and there was no issue of common method variance in the analysis.

\section{Data analysis}

The survey asked the frequency of 41 causes of cost overrun. The importance index (equation (1)), adapted from Mahamid and Bruland (2011), was used to rank the causes of cost overrun based on the frequency of specific causes as identified by the 160 participants. The Importance Index has also been used by Megha and Rajiv (2013a, 2013b).

$$
\text { Importance Index (II) }=\sum_{1}^{5}(x . f) / n
$$

where, $x$ is the constant expressing weight to each response (ranging from 1 for never to 5 for always), $f$ is the frequency of the response, and $n$ is total number of responses.

Results are shown in Table 3. 
Table 3 Ranking of causes that impact on cost overrun in Saudi Arabia

\begin{tabular}{|c|c|c|c|c|c|c|c|c|}
\hline \multirow[b]{2}{*}{ Causes of cost overrun } & \multicolumn{2}{|c|}{ Overall } & \multicolumn{2}{|c|}{ Owner } & \multicolumn{2}{|c|}{ Contractor } & \multicolumn{2}{|c|}{ Consultant } \\
\hline & $R a$. & II & $R a$. & II & $R a$ & II & $R a$ & $I I$ \\
\hline $\begin{array}{l}\text { Market conditions (materials and } \\
\text { labour) }\end{array}$ & 1 & 4.04 & 1 & 4.05 & 1 & 4.1 & 2 & 3.98 \\
\hline Design changes & 2 & 3.88 & 2 & 3.89 & 2 & 3.9 & 3 & 3.85 \\
\hline $\begin{array}{l}\text { Practice of assigning contract to } \\
\text { lowest bidder }\end{array}$ & 3 & 3.86 & 3 & 3.87 & 3 & 3.88 & 4 & 3.84 \\
\hline $\begin{array}{l}\text { Delays (decision making, in } \\
\text { approval of drawings, material } \\
\text { delivery) }\end{array}$ & 4 & 3.82 & 4 & 3.84 & 4 & 3.83 & 5 & 3.8 \\
\hline Design error & 5 & 3.62 & 5 & 3.6 & 15 & 3 & 6 & 3.65 \\
\hline Deficiencies in the infrastructure & 6 & 3.52 & 6 & 3.51 & 6 & 3.58 & 7 & 3.5 \\
\hline Additional work and rework & 7 & 3.46 & 7 & 3.46 & 7 & 3.5 & 8 & 3.4 \\
\hline Slow payment of completed work & 8 & 3.44 & 8 & 3.43 & 8 & 3.47 & 9 & 3.42 \\
\hline Change in the scope of the project & 9 & 3.38 & 9 & 3.37 & 9 & 3.4 & 10 & 3.38 \\
\hline $\begin{array}{l}\text { Changes in material specifications } \\
\text { and type }\end{array}$ & 10 & 3.36 & 10 & 3 & 10 & 3.02 & 1 & 4.05 \\
\hline Shortage of site workers & 11 & 3.06 & 11 & 3 & 11 & 3.02 & 11 & 3.15 \\
\hline $\begin{array}{l}\text { Incorrect planning and scheduling } \\
\text { by contractors }\end{array}$ & 12 & 3.05 & 12 & 3 & 22 & 3.01 & 12 & 3.15 \\
\hline Cash flow during construction & 13 & 3.01 & 13 & 2.99 & 13 & 3.01 & 13 & 3.02 \\
\hline Inadequate specifications & 14 & 3.01 & 14 & 2.98 & 14 & 3.03 & 14 & 3.01 \\
\hline Obstacles from government & 15 & 2.97 & 37 & 2.23 & 5 & 3.7 & 15 & 2.98 \\
\hline $\begin{array}{l}\text { Unrealistic contract duration and } \\
\text { requirements imposed }\end{array}$ & 16 & 2.96 & 15 & 2.94 & 16 & 2.98 & 16 & 2.97 \\
\hline $\begin{array}{l}\text { Lack of experience of project } \\
\text { (e.g., location, type) }\end{array}$ & 17 & 2.94 & 16 & 2.92 & 17 & 2.95 & 17 & 2.94 \\
\hline Lack of constructability & 18 & 2.91 & 17 & 2.9 & 18 & 2.92 & 18 & 2.9 \\
\hline Strategic misrepresentation & 19 & 2.86 & 18 & 2.83 & 19 & 2.89 & 19 & 2.87 \\
\hline Project size & 20 & 2.86 & 19 & 2.83 & 20 & 2.88 & 21 & 2.86 \\
\hline Inflation & 21 & 2.85 & 20 & 2.82 & 21 & 2.88 & 22 & 2.86 \\
\hline Laws and regulatory frameworks & 22 & 2.85 & 21 & 2.82 & 12 & 2.87 & 23 & 2.86 \\
\hline Failure to price in certain risks & 23 & 2.84 & 22 & 2.8 & 23 & 2.86 & 24 & 2.85 \\
\hline $\begin{array}{l}\text { Contractor's poor site management } \\
\text { and supervision skills }\end{array}$ & 24 & 2.84 & 23 & 2.8 & 24 & 2.86 & 25 & 2.85 \\
\hline $\begin{array}{l}\text { Monthly payment difficulties from } \\
\text { agencies (e.g., contractor, owner) }\end{array}$ & 25 & 2.81 & 24 & 2.79 & 25 & 2.82 & 26 & 2.82 \\
\hline $\begin{array}{l}\text { Late delivery of materials and } \\
\text { equipment }\end{array}$ & 26 & 2.81 & 25 & 2.79 & 26 & 2.82 & 27 & 2.81 \\
\hline Waste on site & 27 & 2.78 & 29 & 2.65 & 37 & 2.5 & 28 & 2.79 \\
\hline Political complexities & 28 & 2.78 & 26 & 2.76 & 27 & 2.79 & 29 & 2.78 \\
\hline $\begin{array}{l}\text { Labour, insurance, work security } \\
\text { or workers' health problems }\end{array}$ & 29 & 2.78 & 27 & 2.76 & 28 & 2.79 & 30 & 2.78 \\
\hline
\end{tabular}


Table 3 Ranking of causes that impact on cost overrun in Saudi Arabia (continued)

\begin{tabular}{|c|c|c|c|c|c|c|c|c|}
\hline \multirow[b]{2}{*}{ Causes of cost overrun } & \multicolumn{2}{|c|}{ Overall } & \multicolumn{2}{|c|}{ Owner } & \multicolumn{2}{|c|}{ Contractor } & \multicolumn{2}{|c|}{ Consultant } \\
\hline & $R a$. & II & $R a$. & II & $R a$ & II & $R a$ & II \\
\hline $\begin{array}{l}\text { Deficiencies in cost estimates } \\
\text { prepared by public agencies }\end{array}$ & 30 & 2.74 & 28 & 2.7 & 29 & 2.76 & 31 & 2.75 \\
\hline Poor financial control on site & 31 & 2.69 & 30 & 2.61 & 30 & 2.73 & 32 & 2.72 \\
\hline Fraudulent practices & 32 & 2.66 & 35 & 2.4 & 31 & 2.7 & 20 & 2.87 \\
\hline Equipment availability and failure & 33 & 2.59 & 31 & 2.58 & 32 & 2.62 & 33 & 2.58 \\
\hline Optimism bias & 34 & 2.57 & 32 & 2.55 & 33 & 2.6 & 34 & 2.57 \\
\hline $\begin{array}{l}\text { Inadequate modern equipment } \\
\text { (technology) }\end{array}$ & 35 & 2.55 & 33 & 2.52 & 34 & 2.58 & 35 & 2.56 \\
\hline Site constraints & 36 & 2.49 & 34 & 2.45 & 35 & 2.55 & 36 & 2.48 \\
\hline $\begin{array}{l}\text { High interest rates charged by } \\
\text { bankers on loans }\end{array}$ & 37 & 2.36 & 36 & 2.25 & 36 & 2.5 & 37 & 2.33 \\
\hline Weather conditions & 38 & 2.31 & 38 & 2.2 & 38 & 2.43 & 38 & 2.3 \\
\hline $\begin{array}{l}\text { Fluctuations in monetary exchange } \\
\text { rate }\end{array}$ & 39 & 2.28 & 39 & 2.15 & 39 & 2.4 & 39 & 2.3 \\
\hline $\begin{array}{l}\text { Social and culture impact (e.g., } \\
\text { problems with neighbours) }\end{array}$ & 40 & 2.11 & 40 & 2.05 & 40 & 2.13 & 40 & 2.15 \\
\hline Heritage material discovery & 41 & 1.5 & 41 & 1.3 & 41 & 1.8 & 41 & 1.4 \\
\hline
\end{tabular}

$\mathrm{Ra}=$ rank out of $41, \mathrm{I}=$ Importance Index (where 5 is most important, and 1 is least important).

Sample of 160 respondents included 37 owners, 83 contractors and 39 consultants.

Table 3 shows the frequency indices of 41 causes of cost overrun and their rankings by the three different respondent groups. The first five causes in the overall ranking have good agreement between the three groups. Nevertheless, there is closer agreement between the overall ranking and the owners. The owner is directly responsible for eight causes of the top 10 causes suggesting that project owners have a significant role in cost overrun in Saudi Arabia.

The top ranked cause of market conditions (fluctuation of material and labour prices) directly affects the cost of conducting the project regardless of the geographical location. Changes in project design often result in scope change and consequently increase the cost of project. The practice of assigning the contract to the lowest bidder often leads to cost increases. The initial face-to-face discussions indicate this is because contractors often try to recoup low project bid costs through excessive variations. Although infrastructure projects in Saudi Arabia are directly responsible to government agencies, the survey indicates that the delays from government agencies in approval often result in cost overrun. Design error also plays a significant role in cost overrun because errors found at a later stage result in much more additional cost. A lack of existing infrastructure such as underground water pipes, electricity and IT cables often made the task of the construction difficult and increased the cost significantly.

Infrastructure projects in Saudi Arabia are normally paid for by government (the Ministry of Finance), where the payment process goes through two government agencies. For example, the contractor sends the payment request to the consultant 
who evaluates the request then sends it to the owner for evaluation (such as the Ministry of Education who plans, designs and supervises education projects) who then sends it to the Ministry of Finance to be paid. This results in slow payment for completed works. As the payment is very slow, this adversely impacts the cash flow during construction and leads to delays of materials and work which contribute to cost overrun. Additional works and rework as a result of poor quality of design or design error also increase the cost. Changes in the scope of the project and changes in material specifications and type are related to an unclear vision of the future project (at the plan and design stage) by the government agencies, as all of Saudi's public infrastructure projects are planned and designed. This is because the construction industry in Saudi Arabia is moving extremely fast; so the scope and design of project problems should be given significant consideration.

The causes of cost overrun which were ranked from 11 to 20 include shortage of skilled workers, incorrect planning and scheduling, obstacles from the government, lack of experience in relation to the project location, type and size of the project.

Causes with a medium impact on cost overrun, ranked below 20 out of 41 , include inflation, laws and regulatory frameworks, failure to price in certain risks, late delivery of materials and equipment, and political complexities, which are related to project environment.

Kendall's Tau coefficient of rank correlation is used to demonstrate whether there is agreement or disagreement among each pair of parties: owners, contractors and consultants. Table 4 shows that there is very good agreement between the three parties in ranking these causes. There is very good correlation between consultants and owners with $88 \%$ agreement between this pair, and interestingly, the same degree of agreement between owners and contractors. Even though some slightly contrary opinions exist between consultants and contractors, the degree of agreement between this pair is about $81 \%$. The very good agreement between the three parties in ranking causes of cost overruns means all the collected data can be used to extend the research including classification of causes and development of a cost contingency model (Allahaim, 2014). Causes can be classified in many ways, including controllable and uncontrollable causes which may vary by project type and project stakeholder, but the aim is to improve understanding in order to minimise cost overrun.

Table 4 Kendall's Tau correlation for rankings between owners, contractors and consultants

\begin{tabular}{lcccc}
\hline & Owner & Contractor & Consultant & Overall \\
\hline Owner & 1.0000000 & 0.8753848 & 0.8803079 & 0.9391520 \\
Contractor & 0.8753848 & 1.0000000 & 0.8104581 & 0.9262000 \\
Consultant & 0.8803079 & 0.8104581 & 1.0000000 & 0.9212799 \\
Overall & 0.9391520 & 0.9262000 & 0.9212799 & 1.0000000 \\
\hline
\end{tabular}

Sample included 37 owners, 83 contractors and 39 consultants.

Of the respondents, $35 \%$ were involved in education projects, $25 \%$ in health projects, $15.5 \%$ in transport projects, $13 \%$ in water projects and $11.5 \%$ in power. Figure 2 shows the cost overrun in infrastructure projects for each type of project. Power and health projects experienced an overall cost overrun of more than $60 \%$, transport and water 
projects experienced an overall cost overrun of around $40 \%$, and education projects experienced an overall cost overrun of around $30 \%$. The overall average cost overrun was $43 \%$, which is similar to the worldwide cost overrun rate. The party causing cost overrun in infrastructure projects was identified as follows: $44 \%$ owners, $34 \%$ contractors, $20 \%$ consultants and $2 \%$ third party such as other stakeholders, or changing of government regulation.

Figure 2 Overall cost overrun by type of project in Saudi Arabia: transport, power, water, education and health

\section{Cost Overrun}

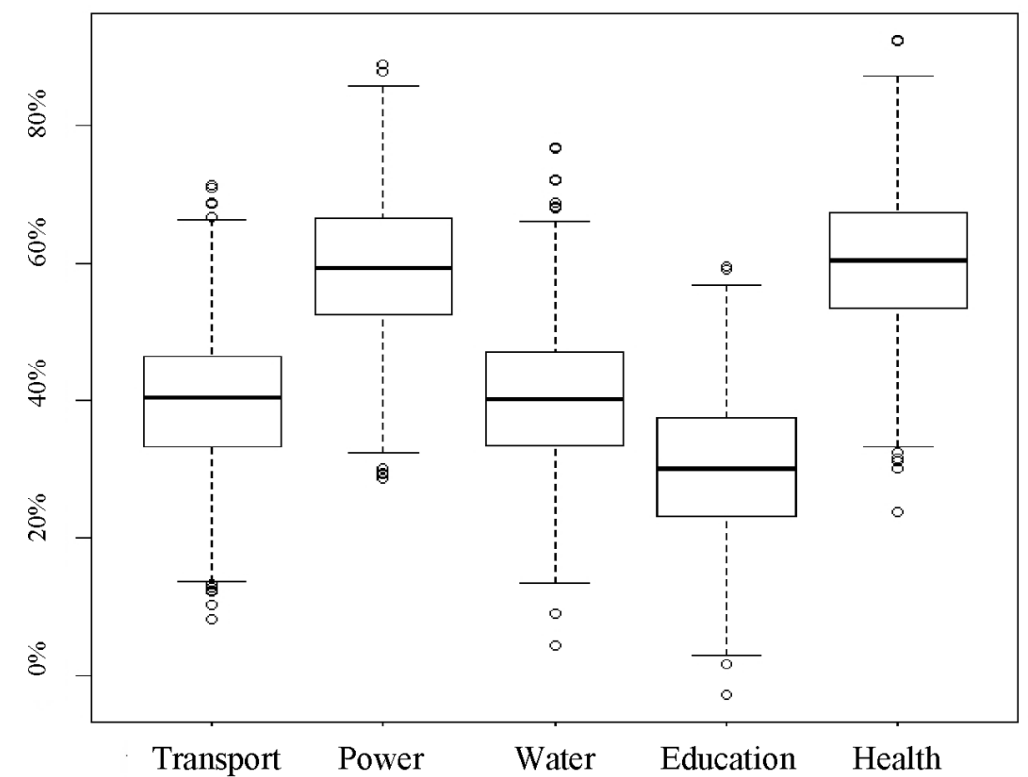

The median cost overrun percentage in each type of project is marked by the solid line inside the 'box' and ranges from $30 \%$ to $60 \%$, while the box is derived from the lower and upper quartile values. The maximum and minimum cost overrun percentage are displayed with vertical lines ('whiskers') connecting the points to the centre box including any outliers (dots) which have cost overrun percentage range from about $-5 \%$ (the smallest outlier) to $90 \%$ (the largest outlier). The shape of the box in all sectors is symmetric. Cost overrun is reported by 160 survey respondents.

\section{Discussion}

The analysis shows that the top five causes of cost overrun in infrastructure projects in Saudi Arabia are market conditions (materials and labour), design changes, the practice of assigning a contract to the lowest bidder, delays in decision making and approval of drawings, and design error (see Table 3). These causes are compared to top causes in selected other studies compiled in Table 5. All studies are similar in relation to the purpose and techniques of surveys, therefore a comparison is useful in order to understand the problems associated with infrastructure projects in different regions. 
Table 5 Comparison of the causes of cost overrun in Saudi Arabia with other countries

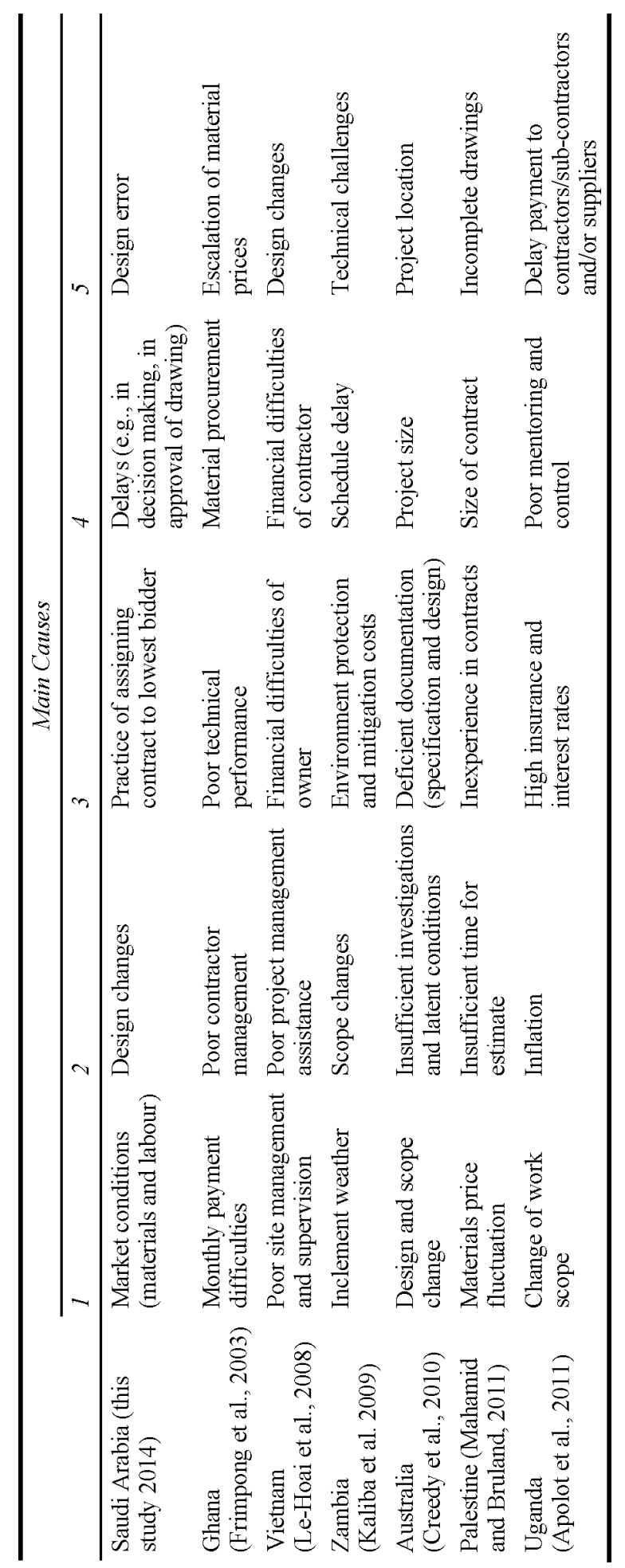


Market conditions including material and labour price fluctuations. It is the most serious cause in Saudi Arabia. Market conditions was also ranked 1 in Palestine and 5 in Ghana (see Table 5). Design changes was the second most serious cause of cost overrun in Saudi Arabia, due to an unclear vision of the future project in terms of location, capacity and available services by government agencies (as the owner representative). This is due to the fact that changes result in extra time and cost. This problem is experienced in Uganda (ranked 1), Zambia (ranked 2), Australia (ranked 2) and Vietnam (ranked 5) (see Table 5).

The practice of assigning a contract to the lowest bidder was found as the third major cause contributing to cost overrun in Saudi Arabia because the contractor often tries recouping project cost by excessive variations. Assigning the contract to the lowest bidder is a condition at the tender stage of all government projects according to the Saudi governance system. This cause of cost overrun is unique to Saudi Arabia unlike other countries.

Delays in decision making and in the approval of drawings caused expenditure increase, not only in Saudi Arabia but also in many other countries, especially in developing countries: Ghana (ranked 1), Vietnam (ranked 3), Palestine (ranked 3), Zambia (ranked 4) and Uganda (ranked 5) (see Table 5). Design error, ranked 5 in Saudi Arabia, partly due to limited experience in dealing with large-scale projects in relation to planning and design, can lead to incomplete project documentation, which can impact on project performance. This cause was also found in Palestine (ranked 5) and Australia (deficient documentation - specifications and design, ranked 3).

The top five common causes of cost overruns of Saudi projects, particularly largescale projects, were also evident in other countries, particularly developing economies. This study contributes to the findings that show that Middle East countries face similar problems on the development path. This is possibly due to the existence of different cultures in the project team or an incorrect expectation of one party of the other and also the local governance system.

Flyvbjerg and his colleagues have published various papers on cost overrun causes for infrastructure projects. According to Flyvbjerg et al. (2002), strategic misrepresentation and optimism bias are major causes of cost overrun. Nevertheless, strategic misrepresentation and optimism bias were ranked 19 and 34 respectively in Saudi Arabia. Interestingly, from the face-to-face discussions in the pilot phase, there was some evidence about those causes from experienced project managers. They agreed those causes can lead to major cost overrun, however it is not the case in Saudi Arabia and it is impossible to ignore the technical causes of cost overrun in Saudi Arabia.

Adding to the factors contributing to cost overrun of Saudi infrastructure projects, this study identified the following causes that contribute to cost overrun: a lack of pre-project planning by contractor and consultant teams, poor coordination with government agencies, inconsistent management strategy of parallel contracts by client, poor communication skills of the client's staff and a lack of participation of stakeholders during the conceptual phase. All of these causes relate to government agencies. One possible explanation is the lack of experience in large-scale projects of these agencies responsible for detailed pre-project planning (Alguwaihes, 2011). This research found a cause of cost overrun unique to Saudi Arabia relating to the outsourcing of labour due to the length of time it takes the Labour Ministry to issue labour visas to non-national workers in the complex system. 
This initial work on causes is being used by the authors in related research on classification of causes and development of a cost contingency model to generate recommendations to improve the practice of cost estimation in project management in Saudi Arabia and other countries. Firstly, the findings of this initial research can be used to develop a classification scheme of causes of cost overrun of infrastructure projects to reduce the dimensionality of causes, and secondly, the results of the classification scheme of causes can be used to develop a cost contingency estimation model to improve current cost forecasting methods to prevent or minimise cost overrun (Allahaim, 2014).

Improved data would assist future research in cost overrun and causes and help mitigate the risks of cost overruns. It is recommended that a database of planned and completed infrastructure projects in Saudi Arabia be developed with data on estimated cost, actual cost, materialised risk factors during the project life cycle, and the strategies to manage the risks of cost overrun, in terms of frequency and impact. Issues to be resolved for a national database in Saudi Arabia include;

- Responsibility for the database: the database could be maintained by the government such as the Ministry of Municipal and Rural Affairs, or by a university.

- Access to the database: it could be a public database, with anyone having access, or it could have password access and be limited to the government or infrastructure professionals.

- Accuracy of information: it is important to ensure information in the database is accurate such as original cost, final cost and any causes of overrun. The different parties in a project may want to understate cost overrun or shift blame for cost overrun.

- Provision of information: the provision of information to the database should be written into all contracts as a condition.

- Dissemination of information: the government could hold an annual conference, seminar or workshop every year to discuss the findings from the database and lead to continuous improvement in project management.

Other countries would face similar issues in establishing a national database. While a country-specific database would assist project practices in that country, a regional or global database would be even more valuable and contribute to reducing the risk of cost overrun.

\section{Conclusion}

This study surveyed infrastructure project managers in Saudi Arabia to identify and rank causes of cost overrun of infrastructure projects. The study identified a number of factors that are unique to Saudi infrastructure projects, particularly visa delays for labour, due to geographical location, cultural practice and governance systems, as well as changes in project management practice over time. The findings have important implications for practice. Saudi Arabia has cost overrun causes different from those identified in previous studies in other countries. Research on specific countries could provide valuable insight unique for the countries studied. Previous research presented a variety of cost overrun causes that occurred at certain periods of time, which indicated that cost overrun causes change over time as project management practice improves due to sharing of information 
in a knowledge-based society. Up-to-date knowledge about cost overrun causes helps to understand the complexity of these causes at different periods of time and therefore minimise the risk. Future research directions building on this research in Saudi Arabia include developing a classification scheme of causes, using the classification scheme to develop a cost contingency estimation model and resolving issues to establish national, regional or global databases to share knowledge.

\section{References}

Al-Arabia (2012) 'Saudi Arabia eying boom in construction valued at $\$ 629$ billion', Al-alarbia net, http://english.alarabiya.net/articles/2012/07/28/228936.html (Accessed 30 November, 2012, Arabic version).

Alguwaihes, M. (2011) 'Management of government projects: hope and reality', The Third Project Management Conference, Saudi Council of Engineers, Riyadh, Saudi Arabia (Arabic version), pp.35-45.

Al-Khaldi, Z.S. (1990) Factors Affecting the Accuracy of Construction Costs Estimating in Saudi Arabia, Master of Science thesis, King Fahd University of Petroleum and Minerals, Saudi Arabia.

Al-Khalil, M.I. and Al-Ghafly, M.A. (1999) 'Delay in public utility projects in Saudi Arabia', International Journal of Project Management, Vol. 17, No. 2, pp.101-106.

Al-Kharashi, A. and Skitmore, M. (2009) 'Causes of delays in Saudi Arabian public sector construction projects', Construction Management and Economics, Vol. 27, No. 1, pp.3-23.

Allahaim, F. (2014) Improving Cost Forecasting Accuracy through Classification of the Causes of Cost Overrun in Infrastructure Projects - Illustration Using Saudi Arabia Survey Data, $\mathrm{PhD}$ thesis (under examination, August 2014), The University of Sydney, Australia.

Al-Sultan, S. (1987) Determination of Construction Contract Duration for Public Projects in Saudi Arabia, Master of Science thesis, King Fahd University of Petroleum and Minerals, Saudi Arabia.

Althaqafy (2012) 'Al-Saudia: Expectations of 40\% projects failed in the next months', Alriyadh Newspaper, m.aawsat.com/content/1353537402274241600/economy (Accessed 28 November, 2012, Arabic version).

Althunian, F. (2010) 'Economic Study has discovered that there are $82 \%$ of the Infrastructure projects in the Kingdom of Saudi Arabia are delayed', Alriyadh Newspaper, 10 May, 2010, Issue 15295, www.alriyadh.com/524151 (Accessed 28 September, 2011, Arabic version).

Apolot, R., Alinaitwe, H. and Tindiwensi, D. (2011) 'An investigation into the causes of delay and cost overrun in Uganda's public sector construction projects', Second International Conference on Advances in Engineering and Technology, Entebbe, Uganda, 30 January-1 February, pp.305-311.

Arditi, D., Akan, G.T. and Gurdamar, S. (1985) 'Reasons for delays in public projects in Turkey, Construction Management and Economics, Vol. 3, No. 2, pp.171-181.

Assaf, S.A. and Al-Hejji, S. (2006) 'Causes of delay in large construction projects', International Journal of Project Management, Vol. 24, pp.349-357.

Assaf, S.A., Al-Khalil, M. and Al-Hazmi, M. (1995) 'Causes of delay in large building construction projects', Journal of Engineering and Management, ASCE, Vol. 11, No. 2, pp.45-50.

Auditor General of Sweden (AGS) (Riksrevisionsverket) (1994) The Swedish National Audit Bureau, Vol. 23, Auditor General of Sweden, Stockholm, Sweden.

Baloyi, L. and Bekker, M. (2011) 'Causes of construction cost and time overruns: the 2010 FIFA World Cup stadia in South Africa', Acta Structilia, Vol. 18, No. 1, pp.51-67.

Berechman, J. and Wu, Q. (2006) Cost Overruns Risk Analysis in Transportation Infrastructure Investments, Working Paper, University of British Columbia and Infrastructure Canada. 
Blake Dawson (2011) Scope for Improvement 2011 Project Risk - Getting the Right Balance and Outcomes, Report by Blake Dawson, Infrastructure Partnerships Australia (IPA), The Australian Constructors Association (ACA) and The Energy Supply Association of Australia (ESAA), www.constructors.com.au/publications/sfi_2011/14623-PUB $\% 20$ Scope $\% 20$ for $\% 20$ Improvement\%202010\%20-\%20REPORT\%20(web).pdf (Accessed 2 November, 2012).

Bubshait, A.A. and Al-Juwait, Y.A. (2002) 'Factors contributing to construction costs in Saudi Arabia', Cost Engineering, Vol. 44, No. 5, p.30.

Cantarelli, C.C., Flyvbjerg, B. and Buhl, S.L. (2012) 'Geographical variation in project cost performance: the Netherlands versus worldwide', Journal of Transport Geography, Vol. 24, pp.324-331.

Caravel (2013) A Review of Project Governance Effectiveness in Australia, Report for Australian Department of Infrastructure and Transport Corporate Plan and the Infrastructure Australia (IA) Charter, March 2013. www.infrastructureaustralia.gov.au/publications/files/CARAVEL_ GROUP_Project_Governance_Effectiveness_March_2013.pdf (Accessed 17 March, 2014).

Cheng, Y., Yu, T., Huang, C., Yu, C. and Yu, C. (2011) 'The comparison of three major occupations for user acceptance of information technology: applying the UTAUT model', iBusiness, Vol. 3, pp.147-158.

Creedy, G.D., Skitmore, M. and Wong, J.K.W. (2010) 'Evaluation of risk factors leading to cost overrun in delivery of highway construction projects', Journal of Construction Engineering and Management, Vol. 136, No. 5, pp.528-536.

Dantata, N., Touran, A. and Schneck, D.C. (2006) Trends in US Rail Transit Project Cost Overrun, Transportation Research Board, Annual Meeting CD3ROM.

Dlakwa, M. and Culpin, M. (1990) 'Reasons for overrun in public sector construction projects in Nigeria', International Journal of Project Management, Vol. 8, No. 4, pp.237-241.

Federal Transit Administration (2003) Predicted and Actual Impacts of New Starts Projects; Capital Cost, Operating Cost and Ridership Data, US Department of Transportation, Washington DC, USA.

Federal Transit Administration (2008) The Predicted and Actual Impacts on New Starts Projects A 2007 (Capital Cost and Ridership), US Department of Transportation, Washington DC, USA.

Flyvbjerg, B. (2007) Eliminating Bias through Reference Class Forecasting and Good Governance, Concept Report No. 17, Chapter 6, NTNU, Norway, pp.90-110.

Flyvbjerg, B. (2009) 'Survival of the unfittest: why the worst infrastructure gets built - and what we can do about it', Oxford Review of Economic Policy, Vol. 25, No. 3, pp.344-367.

Flyvbjerg, B. (2014) 'What you should know about megaprojects and why: an overview', Project Management Journal, Vol. 45, No. 2, pp.6-19, Available at SSRN: http://ssrn.com/ abstract $=2424835$

Flyvbjerg, B. and COWI (2004) Procedures for Dealing with Optimism Bias in Transport Planning, British Department of Transport, London.

Flyvbjerg, B., Bruzelius, N. and Rothengatter, W. (2003) Megaprojects and Risk: An Anatomy of Ambition, Cambridge University Press, Cambridge.

Flyvbjerg, B., Holm, M.S. and Buhl, S. (2002) 'Underestimating costs in public works projects', APA Journal, Summer, Vol. 68, No. 3, pp.279-295.

Flyvbjerg, B., Holm, M.S. and Buhl, S. (2005) 'How (in)accurate are demand forecasts in public works projects', Journal of the American Planning Association, Vol. 71, No. 3, pp.131-146.

Frimpong, Y., Oluwoye, J. and Crawford, L. (2003) 'Causes of delay and cost overruns in construction of groundwater projects in a developing countries: Ghana as a case study', International Journal of Project Management, Vol. 21, pp.321-326.

Indiana Department of Transportation (INDOT) (2004) An Analysis of Cost Overruns and Time Delays of INDOT Projects, Federal Highway Administration, Indiana Purdue University, West Lafayette, India. 
Iyer, K.C. and Jha, K.N. (2005) 'Factors affecting cost performance: evidence from Indian construction projects', International Journal of Project Management, Vol. 23, No. 4, pp.283-295.

Jomaah, J., Bafail, A., Abdulaal, R. and Shalapy, M. (2014) 'Identifying, assessing, and evaluating risks affecting the educational construction projects in Saudi Arabia', Journal of International Academic Research for Multidisciplinary, Vol. 1, No. 12, pp.119-140.

Kaliba, C., Muya, M. and Mumba, K. (2009) 'Cost escalation and schedule delays in road construction projects in Zambia', International Journal of Project Management, Vol. 27, No. 5, pp.522-531.

Kaming, P.F., Olomolaiye, P.O., Holt, G.D. and Harris, F.C. (1997) 'Factors influencing construction time and cost overruns on high-rise projects in Indonesia', Construction Management and Economics, Vol. 15, No. 1, pp.83-94.

Koushki, P.A., Al-Rashid, K. and Kartam, N. (2005) 'Delays and cost increases in the construction of private residential projects in Kuwait', Construction Management and Economics, Vol. 23, No. 3, pp.285-294.

Kousliki, P.A. and Kartan, N. (2004) 'Impact of construction materials on project time and cost in Kuwait', Journal of Construction and Architectural Management, Vol. 11, No. 2, pp 126-132.

Le-Hoai, L., Lee, Y. and Lee, J. (2008) 'Delay and cost overruns in Vietnam large construction projects: a comparison with other selected countries', KSCE Journal of Civil Engineering, Vol. 12, No. 6, pp.367-377.

Liu, L. and Napier, Z. (2010) 'The accuracy of risk-based cost estimation for water infrastructure projects: preliminary evidence from Australia projects', Construction Management and Economics, Vol. 28, No.1, pp.89-100.

Liu, L., Wehbe, G. and Sisovic, J. (2010) 'The accuracy of hybrid estimating approaches: a case study of an Australian State road and traffic authority', The Engineering Economist, Vol. 55, No. 3, pp.225-245.

Love, P., Edwards, D. and Irani, Z. (2012) 'Moving beyond optimism bias and strategic misrepresentation: An explanation for social infrastructure project costs overruns', Engineering Management, IEEE Transactions, Vol. 59, No. 4, pp.560-571.

Mahamid, I. and Bruland, A. (2011) 'Cost overrun causes in road construction projects: consultants' perspective', The Second International Construction and Project Management IPEDR, Vol. 15, p.610.

Makovšek, D., Tominc, P. and Logožar, K. (2012) 'A cost performance analysis of transport infrastructure construction in Slovenia', Transportation, Vol. 39, No. 1, pp.197-214.

Mansfield, N.R., Ugwu, O.O. and Doran, T. (1994) 'Causes of delay and cost overruns in Nigeria construction projects', International Journal of Project Management, Vol. 4, No. 12, pp.254-260.

Megha, D. and Rajiv, B. (2013a) 'Methodology for ranking of causes of delay for residential construction projects in Indian context', International Journal of Emerging Technology and Advanced Engineering, Vol. 3, No. 3, pp.396-404.

Megha, D. and Rajiv, B. (2013b) 'Critical causes of delay in residential construction projects: case study of Central Gujarat Region of India', International Journal of Engineering Trends and Technology, Vol. 4, No. 4, pp.761-768.

Memon, A., Abdul Rahman, I. and Abdul Aziz, A. (2011) 'Preliminary study on causative factors leading to construction cost overrun', International Journal of Sustainable Construction Engineering and Technology, Vol. 2, No. 1, pp.57-71.

Mitra, S. and Tan, A.W.K. (2012) 'Lessons learned from large construction project in Saudi Arabia', Benchmarking: An International Journal, Vol. 19, No. 3, pp.308-324.

National Audit Office (United Kingdom) (2013) Over-optimism in Government Projects, Report, www.nao.org.uk/wp-content/uploads/2013/12/10320-001-Over-optimism-in-governmentprojects.pdf (Accessed 17 March, 2014).

Odeck, J. (2004) 'Cost overruns in road construction: what are their sizes and determinants', Transport Policy, Vol. 11, No. 1, pp.43-53. 
Office of Program Policy Analysis and Government Accountability January (OPPAGA) (1996) Review of the Florida Department of Transportation's Performance in Controlling Cost Overruns and Delays When Building Roads and Bridges, p.11, Audit Report, www.oppaga.state.fl.us/MonitorDocs/Reports/pdf/9530rpt.pdf (Accessed 17 July, 2011).

Okpala, D.C. and Aniekwu, A.N. (1988) 'Causes of high costs of construction in Nigeria', Journal of Construction Engineering and Management, Vol. 114, No. 2, pp.233-244.

Pickrell, D.H. (1989) Urban Rail Transit Projects: Forecast versus Actual Ridership and Costs, Final Report, No. UMTA-MA-08-9021-89-1, Transportation Research Board, National Academy of Science, Washington DC.

Podsakoff, P.M., MacKenzie, S.B., Lee, J-Y. and Podsakoff, N.P. (2003) 'Common method biases in behavioural research: a critical review of the literature and recommended remedies', Journal of Applied Psychology, Vol. 88, No. 5, pp.879-903.

RGL Forensics, Faber Maunsell/Aecom and Frontier Economics (2010) Ex Post Evaluation of Cohesion Policy Programmes 2000-2006 financed by the European Regional Development Fund in Objective 1 and 2 Regions, ec.europa.eu/regional_policy/sources/docgener/evaluation/ pdf/synthesis_eval2000_2006.pdf(Accessed 17 July, 2011).

Roxas, R.N. and Chalermpong, S. (2008) 'Forecasting inaccuracies in transportation projects in selected South East Asian countries', 16th Annual Conference of the Transportation Science Society of the Philippines, September, Manila, Vol. 19, pp.123-136.

SIKAP (2002) SIKAP Swedish Institute for Transport and Communications Annual Report, SIKAP Swedish Institute for Transport and Communications, Stockholm SIKA Rapport 2000:11.

Singh, R. (2009) Delays and Cost Overruns in Infrastructure Projects: An Enquiry into Extents, Causes and Remedies, Department of Economics, Delhi School of Economics, Centre for Development Economics, Working Paper No. 181.

Skamris, M.K. and Flyvbjerg, B. (1997) 'Inaccuracy of traffic forecasts and cost estimates on large transport projects', Transport Policy, Vol. 4, No. 3, pp.11-146.

Yeo, K.T. (1990) 'Risks, classification of estimates, and contingency management', Journal of Management in Engineering, Vol. 6, No. 4, pp.458-470.

Zain Al-Abidien, H.M. (1983) 'About the effect of delay penalty on the construction of projects and modification proposal', Proceedings of the First Engineering Conference, 14-19 May, King Abdulaziz University, Jeddah, pp.14-22.

\section{Bibliography}

Flyvbjerg, B., Holm, M.S. and Buhl, S. (2004) 'What causes cost overrun in transport infrastructure projects?', Transport Reviews, Vol. 24, No. 1, pp.3-18.

Fouracre, P.R., Allport, R.J. and Thomson, J.M. (1990) The Performance and Impact of Rail Mass Transit in Developing Countries, TRRL Research Report 278, Transport Research Laboratory, Crowthorne, Berkshire, England.

Jaafari, A. (2003) 'Project management in the age of complexity and change', Project Management Journal, Vol. 34, No. 4, pp.47-58.

Ranf, D.E. (2010) 'Cultural differences in project management', Annales Universitatis Apulensis Series Oeconomica, Vol. 2, No. 12, pp.657-662.

Skamris, M.K. and Flyvbjerg, B. (1996) 'Accuracy of traffic forecasts and cost estimates on large transportation projects', Transportation Research Record: Journal of the Transportation Research Board, Vol. 1518, No. 1, pp.65-69.

USA Commercial Service (2010) Doing Business in Saudi Arabia: 2010 Country Commercial Guide for U.S. Companies, USA Department of Commerce, Washington DC, USA. 


\section{Appendix}

\section{Table A1 Summary of selected studies}

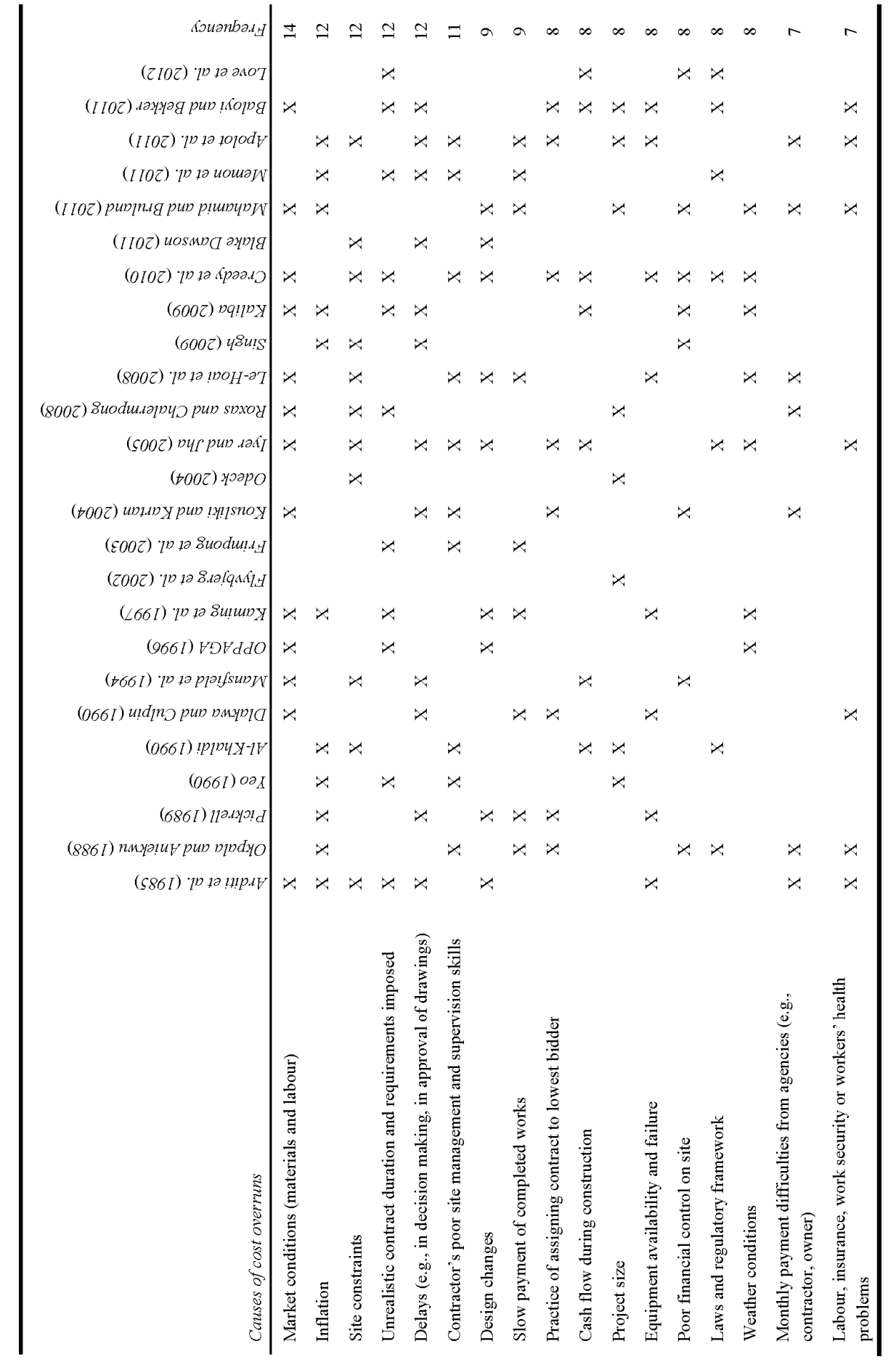


Table A1 Summary of selected studies (continued)

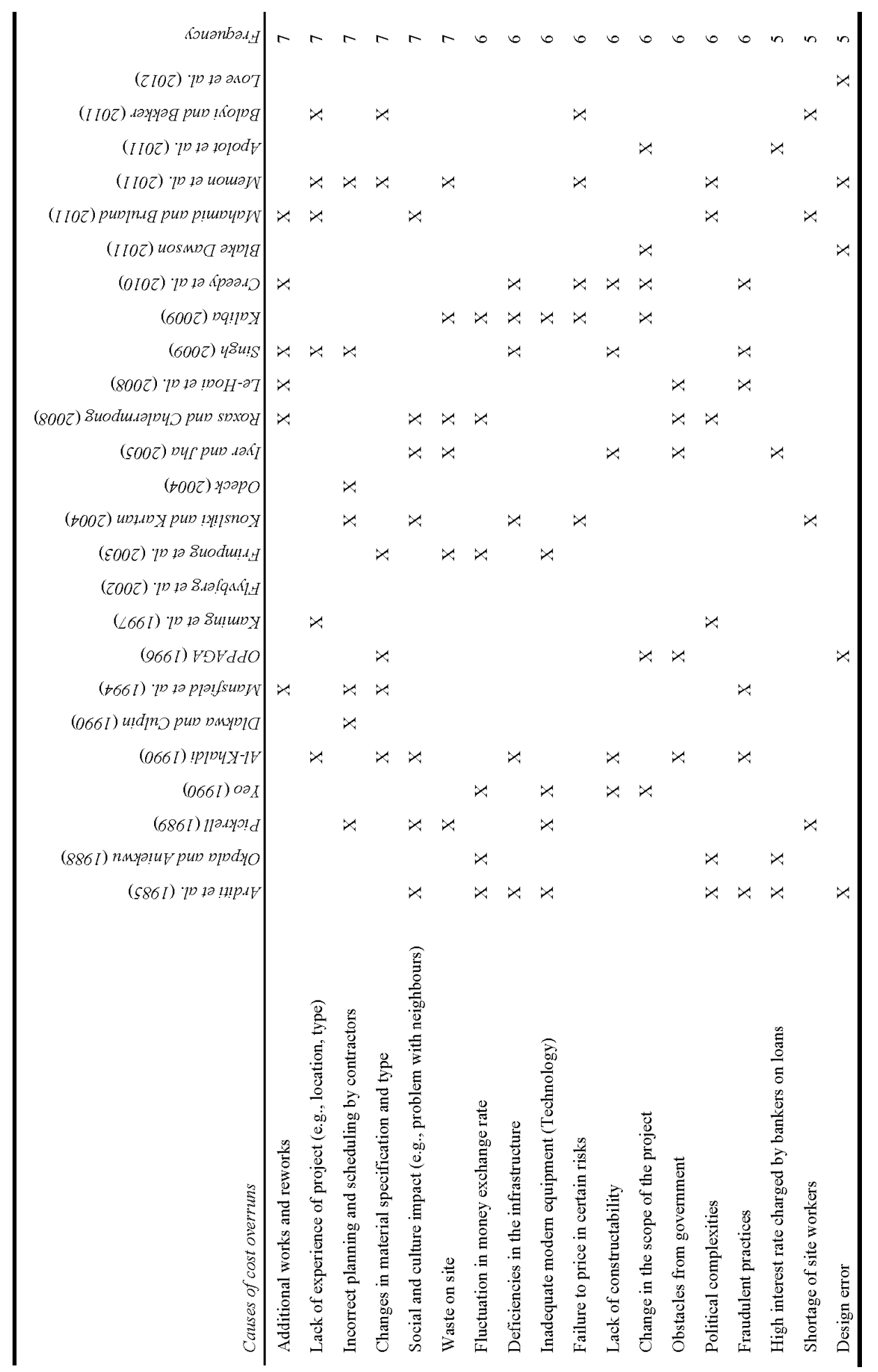


Table A1 Summary of selected studies (continued)

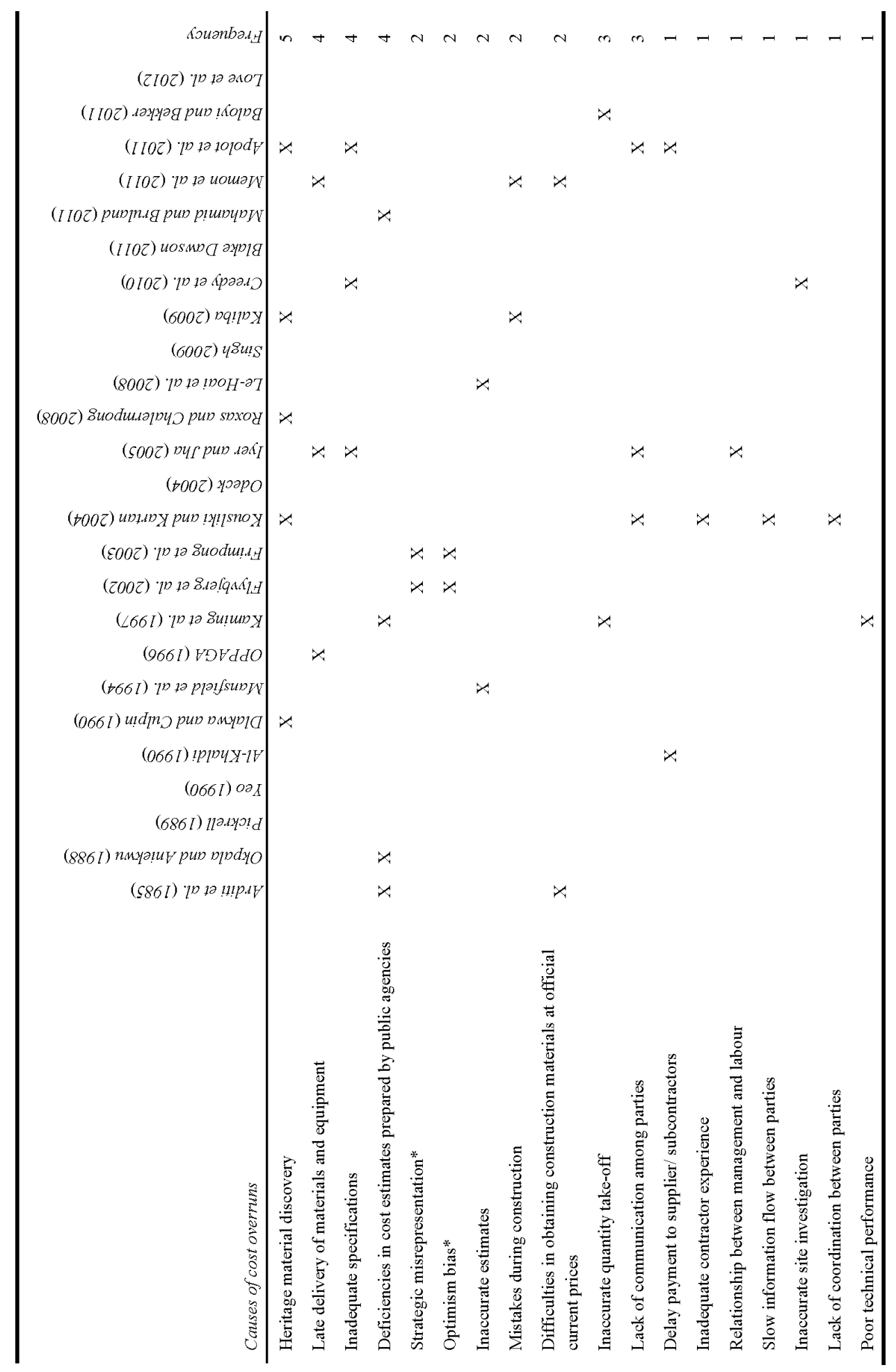


Table A1 Summary of selected studies (continued)

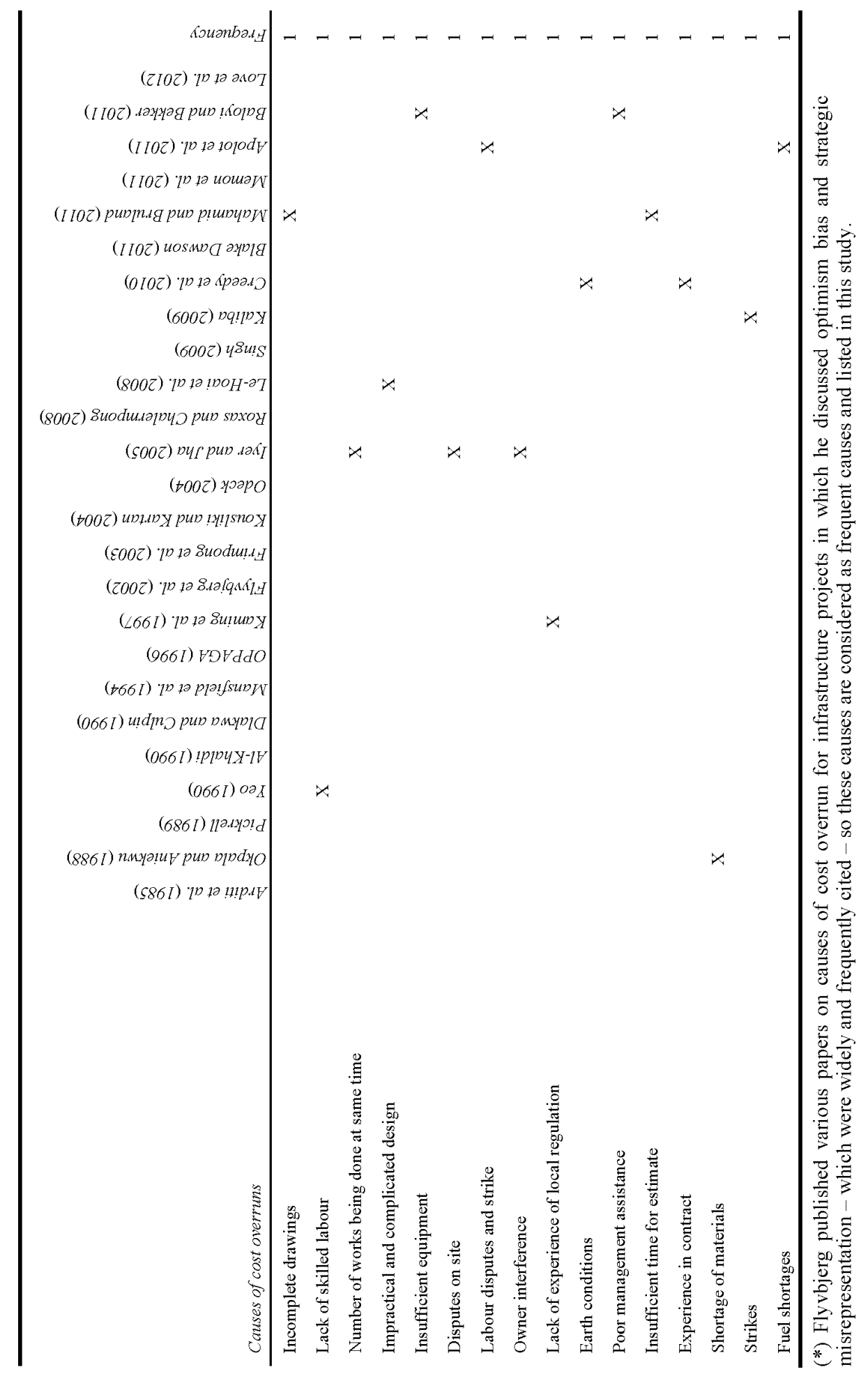

